\title{
Sport als Therapie - Mythos oder Realität
}

Dass eine adäquate Sportausübung auch therapeutische Effekte hat, stellt heutzutage niemand mehr in Frage. Im der aktuellen Ausgabe der sport- und präventivmedizin präsentieren wir Ihnen zu diesem Thema einen außergewöhnlichen und interessanten Fallbericht.

Im Brennpunkt steht diesmal die Otorhinolaryngologie. Auch diesbezüglich werden Ihnen praxisnahe Ratschläge und neueste, wissenschaftliche Erkenntnisse präsentiert: seien es Fakten zu den Tonsillensteinen oder die Tatsache, dass nicht nur Rauchen und Alkohol zu Kopf- und Halstumoren führen, sondern auch Infektionen mit dem Human-Papilloma Virus.

Es ist uns eine große Ehre und Freude, dass wir den ÖSV-Präsidenten Prof. Peter Schröcksnadel für ein sehr persönliches Interview gewinnen konnten. Genießen Sie aber auch die Fortsetzung der Ernährungsmärchen und wir hoffen, dass Ihnen der Medical Cartoon erneut ein Schmunzeln entlockt - denn Lachen ist neben dem Sport die beste Medizin!

Wir wünschen Ihnen, sehr geehrte Leser und Leserinnen, viel Spaß beim Lesen

Mit spätsommerlichen Grüssen!

\section{Univ.-Prof. Dr. Norbert Bachl}

Herausgeber

\author{
Dr. Piero Lercher \\ Editor in Chief
}

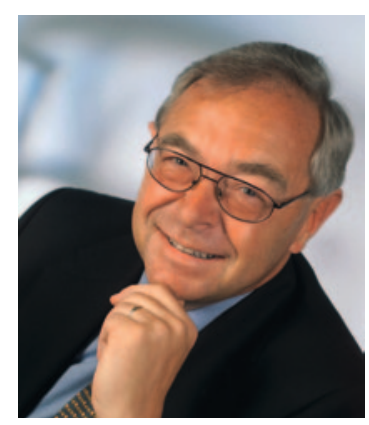

HERAUSGEBER

Univ.-Prof.

Dr. Norbert Bachl

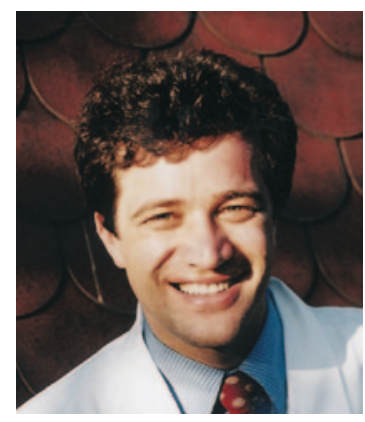

EDITOR IN CHIEF

Dr. Piero Lercher 